\title{
PENERAPAN LAYANAN E-GOVERNMENT DALAM PERWUJUDAN GOOD GOVERNANCE DI PEMERINTAH KOTA MALANG
}

\author{
Riski Febria Nurita \\ Fakultas Hukum Universitas Merdeka Malang \\ Jl. Terusan Raya Dieng No. 62-64 Malang \\ riski.febria@unmer.ac.id
}

\begin{abstract}
Implementation of E-Government in Indonesia and that has been achieved to date, the implementation strategy and E-Government concepts that inevitably require improvements on all sides. The delay in E-Government in development will only make this country away from the ideals of reform, improve the quality of public services to the whole society and ultimately can offend the welfare of society. Implementation of information and communication technology in government and development has become a demand, sooner or later in the era of globalization and regional autonomy that has led to a spirit of openness and empowerment of community potential, the emergence of public expectations of community needs. excellent service and speed Implementation of E-Government in Indonesia, especially in Malang City and the results that have been achieved to date and obstacles that hinder the implementation so that inevitably implementation strategy and E-Government concepts need improvement on all sides should be done as a motivation to build better. The E-Government's delay in development will only keep the country away from reform ideas, improve the quality of public services to the rest of society and ultimately improve welfare.
\end{abstract}

Keywords: Malang City, Electronic Government, Good Governance.

\begin{abstract}
ABSTRAK
Pelaksanaan E-Government di indonesia dan yang telah dicapai hingga saat ini, maka mau tidak mau strategi pelaksanaan dan konsep E-Government memerlukan perbaikan di semua sisi. Keterlambatan E-Government dalam pembangunan hanya akan menjadikan negara ini tetap jauh dari cita cita reformasi, peningkatan kualitas pelayanan publik kepada seluruh masyarakat dan pada akhirnya dapat mengangu kesejahteraan masyarakat. Penerapan teknologi informasi dan komunikasi dalam penyelenggaraan pemerintahan dan pembangunan sudah merupakan tuntutan, cepat atau lambat di era globalisasi dan otonomi daerah yang telah memunculkan semangat keterbukaan dan pemberdayaan potensi masyarakat, timbulnya harapan masyarakat akan kebutuhan pelayanan prima dan kecepatan. Pelaksanaan E-Government di indonesia khususnya di Kota Malang dan hasil yang telah dicapai hingga saat ini serta kedala-kendala yang menghambat pelaksanaanya sehingga mau tidak mau strategi pelaksanaan dan konsep E-Government memerlukan perbaikan di semua sisi haruslah di jadikan sebagai motivasi membangun yang lebih baik. Keterlambatan E-Government dalam pembangunan hanya akan menjadikan negara ini tetap jauh dari cita cita reformasi, peningkatan kualitas pelayanan publik kepada seluruh masyarakat dan akhirnya meningkatkan kesejahteraan.
\end{abstract}

Kata kunci: Kota Malang, Pemerintahan Elektronik, Tata Kelola Pemerintahan yang Baik. 
Istilah teknologi Informasi-TI (Technology Information-IT) digunakan untuk memproses data atau yang dikenal pula dengan pengelolaan sistem informasi (Management Information System-MIS). Istilah Teknologi Informasi pertama kali dikenal di Eropa yaitu pada tahun 1989. Tahun 1989 dilakukan merger antara dua perusahaan teknologi terkenal yaitu Siemens dan Nixdorf. Istilah Tekniologi Informasi dapat dipahami sebagai keseluruhan peralatan, proses, tata cara dan sistem yang digunakan untuk menyediakan dan mendukung sistem informasi di dalam suatu organisasi yang diperuntukkan bagi para pelanggan dan pemasok (Budhijanto, 2010, 257).

Istilah Teknologi Informasi dan KomunikasiTIK (Information and Communication Technology-ICT) dipahami juga sebagai teknologi yang mampu untuk menyimpan, mentransmisikan dan/ atau memproses informasi dan komunikasi. Istilah TIK secara umum lebih sering digunakan untuk penggunaan teknologi yang modern khususnya teknologi-teknologi pemrosesan data secara elektronik. Pemahaman TIK lebih dititikberatkan kepada komputer, telekomunikasi, jaringan komputer, dan telekomunikasi (Budhijanto, 2010, 258).

Teknologi Informasi menurut Pasal 1 angka (3) UU Nomor 11 Tahun 2008 tentang ITE yaitu suatu teknik untuk mengumpulkan, menyiapkan, menyimpan, memproses, mengumumkan, menganalisis, dan/atau menyebarkan informasi. Di Indonesia sendiri penggunaan komputer sudah dimulai sejak tahun 70-an ketika Bank Indonesia menerapkan komputerisasi di kantor pusatnya. Sekitar akhir tahun 1980-an Departemen Pendidikan dan Kebudayaan membangun proyek besar jaringan komputer antar universitas negeri. Jaringan ini dimaksudkan untuk menjalin komunikasi, administrasi, hal akademis di bidang kurikulum perguruan tinggi negeri yang pada saat itu disebut UniNet. Namun, proyek besar tersebut gagal sehingga hanya Institut Teknologi Bandung dan Universitas Indonesia yang tetap mengembangkan infrastruktur ini.
Masuk pada tahun 1995 wakil presiden Amerika Serikat Al Gore mencanangkan penggunaan internet untuk mendorong globalisasi dunia dan pembentukan global knowledge (Budhijanto, 2010, 42). Pada awal masa pengembangan internet di Negara Amerika kita dapat menemukan pertama kali alamat situs pemerintah Amerika Serikat sebagai www.firstgov.gov, kita dapat jumpai pula nama-nama domain seperti, "com", "edu", "ac", "gov" serta domain nama sebuah Negara yang dibagi menjadi dua huruf seperti misalnya "uk" untuk inggris, "my" untuk Malaysia dan tak ketinggalan "id" untuk Indonesia.

Penggunaan teknologi Internet oleh rakyat Amerika Serikat dimanfaatkan agar bias saling berkomunikasi tanpa hambatan khususnya komunikasi antara rakyat dengan pemerintah. Rakyat Amerika Serikat bisa langsung berkomunikasi dengan presidennya tanpa harus melewati ketatnya barisan pengawal Gedung Putih melalui alamat email; president@whitehouse.gov (Budhijanto, 2010, 42). Hal inilah dimulai muncul di berbagai Negara beramai-ramai membuat sebuah website pemerintahan di masing-masing Negara begitu pula di Indonesia website inilah yang biasa kita kenal dengan istilah Electronic Government atau biasa kita sebut dengan E-Government.

Tahun 2003 dalam kaitannya dengan E-Government presiden mengeluarkan INPRES Nomor 3 Tahun 2003 tentang Kebijakan dan Strategi Nasional Pengembangan E-Government presiden menginstruksikan diantaranya kepada Menteri, Kepala Lembaga Pemerintah Non Departemen, Pimpinan Kesekretariatan Lembaga Tertinggi atau Tinggi Negara, Panglima TNI, Kepala Kepolisian Negara Republik Indonesia, Jaksa Agung Republik Indonesia, Gubernur, Bupati/ Walikota. E-Government pada dasarnya bertujuan untuk memenuhi Pasal 28 C Ayat 1 dan Pasal 28 F Undang-Undang Dasar Republik Indonesia Tahun 1945, dimana dalam pasal tersebut tertulis bahwa: "Setiap orang berhak 
mengembangkan diri melalui pemenuhan kebutuhan dasarnya, berhak mendapat pendidikan dan memperoleh manfaat dari ilmu pengetahuan dan teknologi, seni dan budaya, demi meningkatkan kualitas hidupnya dan demi kesejahteraan umat manusia".

Pasal 28 F Undang-Undang Dasar Republik Indonesia Tahun 1945 dinyatakan bahwa "Setiap orang berhak untuk berkomunikasi dan memperoleh informasi untuk mengembangkan pribadi dan lingkungan sosialnya, serta berhak untuk mencari, memperoleh, memiliki, menyimpan, mengolah, dan menyampaikan informasi dengan menggunakan segala jenis saluran".

Dengan terbitnya Inpres pada tahun 2003 tersebut termasuk diinstruksikan kepada kepala daerah di Indonesia maka kaitannya dengan kota Malang melalui pemerintah kota Malang sendiri memulai pelaksanaan pengembangan E-Government melalui program pembangunan jaringan "Malang online" sejak tahun 2003 (Suparto, 2006). Tujuan yang ingin dicapai dengan implementasi E-Goverment di kota Malang sendiri adalah untuk memberikan pelayanan tanpa adanya intervensi pegawai institusi publik dan sistem antrian yang panjang hanya untuk mendapatkan suatu pelayanan yang sederhana. Selain itu E-Goverment juga bertujuan untuk mendukung good governance. Jenisjenis pelayanan dari e- Government yang dikeluarkan di kota Malang meliputi 3 hal antara lain; Pelayanan data dan Informasi melalui website, Pelayanan pengaduan online, serta Pelayanan akses internet.

\section{Pengertian E-Government}

Bank Dunia atau (World Bank) mendefinisikan E-Government sebagai berikut: "E-Government refers to the use by government agencies of information technologies (such as Wide Area Networks, the Internet, and mobile computing) that have the ability to transform relations with citizens, businesses, and other arms of government" (Indrajit, 2002, 2). Penggunaan teknologi informasi oleh kantor-kantor pemerintah untuk pelayanan lebih baik pada masyarakat dunia usaha dan untuk memperbaiki kerjasama antar institusi pemerintah.

UNDP (United Nation Development Programme) mendefinisikan E-Government sebagai berikut: " $E$ Government is the application of information and communication Technology (ICT) by governments agencies" (Indrajit, 2002, 2). (E-Government adalah aplikasi teknologi informasi dan komunikasi (TIK) oleh lembaga pemerintah). Instruksi Presiden RI Nomor 3 Tahun 2003 mendefinisikan E-Government sebagai, pemanfaatan teknologi komunikasi dan informasi dalam proses pemerintahan yang akan meningkatkan efisiensi, efektivitas, transparansi dan akuntabilitas penyelenggaraaan pemerintahan.

Keputusan Kepala Kantor Pengolahan Data Elektronik Kota Malang, definisi E-Government yaitu, Penggunaan Internet untuk melaksanakan urusan pemerintah dan penyediaan pelayanan publik yang lebih baik dan cara yang berorientasi pada pelayanan masyarakat. Menurut Walikota Malang Drs. Peni Suparto definisi E-Government yaitu bentuk implementasi pelayanan publik yang berbasis teknologi informasi dan komunikasi, sebagai media informasi dan sarana komunikasi interaktif antara Pemerintah dengan pihak-pihak lain baik kelompok masyarakat, kalangan bisnis maupun antar sesama lembaga pemerintahan (Suparto, 2006).

Berdasarkan seluruh kajian definisi tersebut diatas maka dapat diperoleh tiga kesamaan dari setiap definisi E-Government, yaitu masing-masing adalah: 1) Merupakan suatu mekanisme interaksi baru (modern) antara pemerintah dengan masyarakat dan kalangan lain yang berkepentingan (stakeholder), 2) Melibatkan penggunaan teknologi informasi (terutama melalui teknologi internet), 3) Memperbaiki kualitas pelayanan ke arah yang lebih baik cepat, mudah, transparan dan biaya ringan.

\section{Manfaat dan Tujuan Layanan E-Government}

Dua negara besar yang terdepan dalam mengimplementasikan konsep E-Government, yaitu 
Amerika dan Inggris melalui $\mathrm{Al}$ Gore dan Tony Blair, telah secara jelas dan terperinci menggambarkan manfaat yang diperoleh dengan diterapkannya konsep E-Government bagi suatu negara, antara lain:

1) Memperbaiki kualitas pelayanan pemerintah kepada para stakeholder-nya (masyarakat, kalangan bisnis dan industri) terutama dalam hal kinerja efektivitas dan efisiensi di berbagai bidang kehidupan bernegara;

2) Meningkatkan transparansi, kontrol, dan akuntabilitas penyelenggaraan pemerintahan dalam rangka penerapan konsep Good Corporate Governance;

3) Mengurangi secara signifikan total biaya administrasi, relasi, dan interaksi yang dikeluarkan pemerintah maupun stakeholdernya untuk keperluan aktivitas sehari-hari;

4) Memberikan peluang bagi pemerintah untuk mendapatkan sumber-sumber pendapatan baru melalui interaksinya dengan pihak-pihak yang berkepentingan;

5) Menciptakan suatu lingkungan masyarakat baru yang dapat secara cepat dan tepat menjawab berbagai permasalahan yang dihadapi sejalan dengan berbagai perubahan global dan trend yang ada; dan

6) Memberdayakan masyarakat dan pihak-pihak lain sebagai mitra pemerintah dalam proses pengambilan berbagai kebijakan publik secara merata dan demokratis (Indrajit, 2002, 5).

Dengan kata lain, negara-negara maju memandang bahwa implementasi E-Government yang tepat akan secara signifikan memperbaiki kualitas kehidupan masyarakat di suatu negara secara khusus, dan masyarakat dunia secara umum. Oleh karena itu, implementasinya di suatu negara selain tidak dapat ditunda-tunda harus pula dilaksanakan secara serius.

Melaksanakan maksud dari pengembangan layanan E-Government di Indonesia sendiri diarahkan untuk mencapai 4 (empat) tujuan, yaitu: a) Pembentukan jaringan Informasi dan transaksi pelayanan publik yang memiliki kualitas dan lingkup yang dapat memuaskan masyarakat luas serta dapat terjangkau di seluruh wilayah Indonesia pada setiap saat tidak dibatasi oleh sekat waktu dan dengan biaya yang terjangkau oleh masyarakat;

b) Pembentukan hubungan interaktif dengan dunia usaha untuk meningkatkan perkembangan perekonomian nasional dan memperkuat kemampuan menghadapi perubahan dan persaingan perdagangan internasional;

c) Pembentukan mekanisme dan saluran komunikasi dengan lembaga-lembaga negara serta penyediaan fasilitas dialog publik bagi masyarakat agar dapat berpartisipasi dalam perumusan kebijakan Negara;

d) Pembentukan sistem manajemen dan proses kerja yang transparan dan efisien serta memperlancar transaksi dan layanan antar lembaga pemerintah dan pemerintah daerah otonom.

\section{Empat Tipe Relasi E-Government}

E-Government dikenal pula empat jenis klasifikasi, yaitu G-to-C, G-to-B, G-to-G, dan G-to-E.

a. Government to Citizens

Tipe G-to-C ini merupakan aplikasi E-Government yang paling umum, yaitu dimana pemerintah membangun dan menerapkan berbagai teknologi informasi dengan tujuan utama untuk memperbaiki hubungan interaksi dengan masyarakat (rakyat). Dengan kata lain, tujuan utama dari dibangunnya aplikasi E-Government bertipe G-to-C adalah untuk mendekatkan pemerintah dengan rakyatnya melalui kanalkanal akses yang beragam agar masyarakat dapat dengan mudah menjangkau pemerintahannya untuk pemenuhan berbagai kebutuhan pelayanan sehari-hari (Indrajit, 2002, 42).

b. Government to Business

Salah satu tugas utama dari sebuah pemerintahan adalah membentuk sebuah lingkungan 
bisnis yang kondusif agar roda perekonomian sebuah negara dapat berjalan sebagaimaan mestinya. Dalam melakukan aktivitas sehariharinya, perusahaan swasta membutuhkan banyak sekali data dan informasi yang dimiliki oleh pemerintah. Disamping itu, perusahaanperusahaan swasta juga harus berinteraksi dengan berbagai lembaga kenegaraan karena berkaitan dengan hak dan kewajiban organisasinya sebagai sebuah perusahaan bisnis yang berorientasi profit oriented (Indrajit, 2002, 43).

c. Government to Governments

Di era globalisasi ini terlihat jelas adanya kebutuhan bagi negara-negara untuk saling berkomunikasi secara lebih intens dari hari ke hari. Kebutuhan untuk berinteraksi antar satu pemerintah dengan pemerintah setiap harinya tidak hanya berkisar pada hal-hal kenegaraan atau diplomnasi semata, namun lebih jauh lagi untuk memperlancar kerjasama antar negara dan kerjasama antar entiti negara (masyarakat, industri, perusahaan, dan lain-lain) dalam melakukan hal-hal yang berkaitan dengan administrasi perdagangan, proses-proses politik, mekanisme hubungan social dan budaya, dan lain sebagainya (Indrajit, 2002, 44).

d. Government to Employess

Aplikasi E-Government juga diperuntukkan untuk meningkatkan kinerja dan kesejahteraan para pegawai negeri atau karyawan pemerintahan yang bekerja di sejumlah institusi sebagai pelayan masyarakat (Indrajit, 2002, 44-45). Berbagai jenis aplikasi yang dapat dibangun misalnya saja kemudahan Asuransi Kesehatan (AsKes), pembangunan karir pegawai sebagai penunjang proses mutasi, rotasi dan lain-lain, kemudahan pembayaran Pajak Penghasilan pegawai $(\mathrm{PPH})$, dan lain sebagainya.

\section{Pelayanan Publik Berbasis E-Government}

Beragam tipe pelayanan yang ditawarkan oleh pemerintah kepada masyarakatnya melalui $E$ -
Government. Salah satu cara mengkategorikan jenisjenis pelayanan tersebut adalah dengan melihatnya dari dua aspek utama yaitu;

a) Aspek Kompleksitas, yaitu menyangkut seberapa rumit anatomi sebuah aplikasi E-Government yang ingin dibangun dan diterapkan; dan

b) Aspek Manfaat, yaitu menyangkut hal-hal yang berhubungan dengan besarnya manfaat yang dirasakan oleh para penggunanya (Indrajit, 2002, 29).

Berdasarkan dua aspek di atas, maka jenisjenis proyek E-Government dapat dibagi menjadi tiga kelas utama, yaitu Publish, Interact, dan Transact. (Indrajit, 2002, 29).

\section{Publish}

Jenis ini merupakan implementasi E-Government yang termudah karena selain proyeknya yang berskala kecil, kebanyakan aplikasinya tidak perlu melibatkan sejumlah sumber daya yang besar dan beragam. Di dalam kelas Publish ini yang terjadi adalah sebuah komunikasi satu arah, dimana pemerintah mempublikasikan sebagai data dan informasi yang dimilikinya untuk dapat secara langsung dan bebas diakses oleh masyarakat dan pihak-pihak lain yang berkepentingan melalui internet (Indrajit, 2002, 30).

\section{Interact}

Berbeda dengan kelas Publish yang sifatnya pasif, pada kelas Interact telah terjadi komunikasi dua arah antara pemerintah dengan mereka yang berkepentingan. Ada dua jenis aplikasi yang biasa dipergunakan. Pertama adalah bentuk portal dimana situs terkait memberikan fasilitas searching bagi mereka yang ingin mencari data atau informasi secara spesifik (pada kelas Publish, pengguna hanya dapat mengikuti link saja). Kedua adalah pemerintah menyediakan kanal dimana masyarakat dapat melakukan diskusi dengan unit-unit tertentu yang berkepentingan, baik secara langsung (seperti chatting, tele-conference, web-TV dsb) 
maupun tidak langsung (melalui email, newsletter dll) (Indrajit, 2002, 31).

3. Transact

Kelas ini adalah kelas dua arah seperti pada kelas Interact, hanya saja terjadi sebuah transaksi yang berhubungan dengan perpindahan uang dari satu pihak ke pihak lainnya (tidak gratis, masyarakat harus membayar jasa pelayanan yang diberikan oleh pemerintah atau mitra kerjanya). Selain memperlihatkan dimensi kompleksitas dan manfaat, klasifikasi ini dapat pula dipergunakan sebagi sebuah inisiatif dari E-Government dari yang paling sederhana sampai yang paling canggih (Indrajit, 2002, 32-33).

\section{Perwujudan Good Governance di Kota Malang Melalui E-Government}

Penerapan teknologi informasi dan komunikasi dalam penyelenggaraan pemerintahan dan pembangunan sudah merupakan tuntutan, cepat atau lambat di era globalisasi dan otonomi daerah yang telah memunculkan semangat keterbukaan dan pemberdayaan potensi masyarakat, timbulnya harapan masyarakat akan kebutuhan pelayanan prima dan kecepatan dalam mengakses informasi, mengharuskan Pemerintah Daerah untuk segera menerapkan teknologi informasi dalam proses penyelenggaraan pemerintahan melalui implementasi E-Government secara terintegrasi.

Di Kota Malang, bersamaan dengan terbitnya Inpres No. 3 Tahun 2003 tentang kebijakan dan strategi Nasional pengembangan E-Government, sudah memulai pelaksanaan pengembangan E-Government melalui program pembangunan jaringan "Malang Online" sebagai langkah awal dalam penyediaan infrastruktur telematika yang dilaksanakan secara bertahap dalam setiap tahun dimulai sejak tahun anggaran 2003. Menyesuaikan dengan tujuan dan strategi Nasional dalam pengembangan E-Government, kebijakan pengem- bangan E-Government melalui program "Malang Online" diarahkan dengan maksud dan tujuannya adalah membangun sistem informasi dan komunikasi.

Adapun fungsi teknologi informasi dan manfaat komputer yang diterapkan di kota malang, yakni:

1. Fungsi Internet (Jaringan Global)

a. Menyebarkan informasi seluas-luasnya mengenai potensi Kota Malang;

b. Agar aparatur Pemerintah Kota Malang semakin memahami secara luas seputar teknologi informasi dan komunikasi khususnya dalam perkembangannya di Indonesia dan mancanegara.

2. Fungsi Internet (jaringan lokal)

a. Mempermudah aparatur Pemerintah Kota Malang untuk melakukan koordinasi, komunikasi dan transformasi data antar unit kerja;

b. Mempermudah unsur pimpinan Pemerintah Kota Malang untuk melakukan pemantauan dan koordinasi internal antar unit kerja terhadap data-data atau informasi perkembangan pembangunan yang terbaru (uptodate).

c. Meningkatkan kebutuhan informasi dalam organisasi Pemerintah Kota Malang, yaitu pelayanan informasi, pelayanan interaktif, dan pelayanan kepada masyarakat yang lebih baik, sehingga kebutuhan informasi baik intern Pemerintah Kota Malang maupun ekstern (masyarakat) dapat terlayani secara cepat, baik dan benar;

d. Mendukung dan memajukan kesiapan akan perkembangan teknologi dalam menunjang peningkatan kinerja dan pelayanan pemerintah terhadap public;

e. Sosialisasi E-Government yang lebih signifikan melalui pemahaman secara aplikatif guna mendukung kesiapan Pemerintah Kota dalam menghadapi dan menyele- 
saikan berbagai permasalahan di masa depan;

f. Terciptanya mekanisme pengambilan keputusan secara berdaya guna dan berhasil guna, dalam upaya menunjang keberhasilan penyelenggaraan pemerintahan, pembangunan dan kemasyarakatan (Suparto, 2006).

Jenis-jenis pelayanan dari $e$-Government yang dikeluarkan di kota Malang meliputi 3 (tiga) hal antara lain: Pelayanan data dan Informasi melalui website, Pelayanan pengaduan online, serta Pelayanan akses internet. Dengan adanya transformasi dari sistem pemerintahan tradisional (manual) ke sistem pemerintahan elektronik (E-Government), beberapa perubahan diharapkan semakin mempercepat pembangunan dan mewujudkan sistem dan tata kelola pemerintahan yang bersih, transparan, efektif, efisien, dan akuntabel.

Berbagai manfaat diperoleh dalam membangun jaringan "Malang OnLine". Dengan adanya jaringan komputer yang menghubungkan seluruh unit kerja dilingkungan Pemerintah Kota Malang, diantaranya resource sharing, reliabilitas tinggi, lebih ekonomis, skalabilitas dan sebagai media komunikasi yang efektif. Resource sharing bertujuan agar seluruh program, peralatan, khususnya data dapat dipergunakan oleh setiap orang dalam unit kerja yang menggunakan komputer (PC) yang terhubung dalam jaringan tersebut tanpa terpengaruh oleh lokasi resource dan pemakai.

Jadi source sharing adalah suatu usaha untuk menghilangkan kendala jarak. Dengan menggunakan jaringan komputer, akan memberikan reliabilitas tinggi yaitu adanya sumber-sumber alternatif pengganti jika terjadi masalah pada salah satu perangkat dalam jaringan, artinya karena perangkat yang digunakan lebih dari satu, jika salah satu perangkat mengalami masalah, maka perangkat yang lain dapat menggantikannya. Skalabilitas yaitu kemampuan untuk meningkatkan kinerja sistem secara berangsur-angsur sesuai dengan beban pekerjaan dengan hanya menambah sejumlah prosesor.

Komputer mainframe yang tersentralisasi, jika sistem sudah jenuh maka komputer harus diganti dengan komputer yang mempunyai kemampuan kapasitasnya yang lebih besar. Hal ini membutuhkan biaya yang lebih besar dan dapat menyebabkan gangguan terhadap kontinuitas kerja para pemakai. Sebuah jaringan komputer mampu bertindak sebagai media komunikasi yang baik bagi pegawai yang terpisah letak lokasi tempat pekerjaannya.

Dengan menggunakan jaringan, memungkinkan seluruh unit kerja akan lebih mudah melakukan komunikasi untuk suatu kerjasama dalam penyusunan laporan maupun program. Ada bermacam-macam bentuk akses ke informasi jarak jauh yang dapat dilakukan, terutama setelah berkembangnya teknologi internet, berita-berita di koran sekarang dapat di download ke komputer kita melalui internet, dan tidak hanya itu sekarang dapat melakukan transaksi bisnis melalui internet yang dikenal dengan istilah e-commerce.

Dengan fasilitas internet kita juga dapat melakukan komunikasi orang ke orang melalui fasilitas e-mail dan chatting. Web camera merupakan perangkat teknologi yang memungkinkan dilaksanakannya komunikasi langsung tatap muka melalui internet, dapat dimanfaatkan untuk teleconference antara pejabat dengan masyarakat atau untuk media komunikasi dalam rangka koordinasi antar para pejabat unit kerja. Sedangkan sasaran secara khusus pembangunan jaringan "Malang Online" adalah

1. Terciptanya mekanisme penyediaan informasi dalam rangka pengambilan keputusan di lingkungan Pemerintah Kota Malang dan seluruh jajarannya secara berdayaguna dan berhasil guna;

2. Terciptanya Sistem Informasi Manajemen (SIM) yang dapat menghubungkan setiap perangkat 


\section{Penerapan Layanan E-Government dalam Perwujudan Good Governance di Pemerintah Kota Malang}

Riski Febria Nurita

organisasi dalam jajaran Pemerintah Kota agar terbentuk suatu jaringan komunikasi data untuk memperlancar arus informasi timbal balik secara terarah (Suparto, 2006).

Sehingga dengan adanya layanan E-Government maka perwujudan Good Governance dapat tercapai, karena di dalam good governance terdapat peranan 3 (tiga) domain yang membantu mewujudkan good governance dalam pelayanan publik diantaranya:

a. The State

Diantara tugas terpenting negara (states) pada masa ke depan yang diciptakan oleh lingkungan politik adalah mewujudkan pembangunan manusia yang berkelanjutan dengan meredifinisi peran pemerintahan dalam mengintegrasikan sosial, ekonomi dan melindungi kerentanan dalam masyarakat, menciptakan komitmen politik mengenai restrukturisasi ekonomi, sosial dan politik, menyediakan infrastruktur, desentralisasi dan demokratisasi pemerintah, memperkuat financial dan kapasitas administratif pemerintah lokal, kota dan metropolitan (Widodo, 2001, 20).

Institusi pemerintah akan memiliki peran penting dalam melindungi lingkungan, memelihara harmonisasi sosial, ketertiban dan keamanan, stabilisasi kondisi makro-ekonomi, meningkatkan penerimaan keuangan dan menyediakan pelayanan publik dan infrastruktur yang esensial, memelihara standar keselamatan dan kesehatan masyarakat dengan biaya yang dapat dijangkau mengatur aktivitas ekonomi yang bersifat "natural monopolies" atau yang dapat mempengaruhi kesejahteraan umum bagi warga Negara (Widodo, 2001, 21).

b. The Private Sector

Pasar dan sektor swasta jelas telah memainkan peran penting dalam pembangunan dengan menggunakan pendekatan pasar (market approach). Pendekatan pasar untuk pembangunan ekonomi berkaitan dengan penciptaan kondisi di mana produksi barang dan jasa (goods and services) berjalan dengan baik dengan dukungan dari lingkungan yang mapan untuk melakukan aktivitas sector swasta dan dalam suatu bingkai kerja "incentives and rewards" secara ekonomi bagi individu dan organisasi yang memiliki kinerja baik (Widodo, 2001, 21).

c. Civil Society

Menurut Bintoro Tjokroamidjojo civil society yang dimaksud disini yaitu manusia dan masyarakat yang berdaya (empowered) yaitu; (1) Berpengetahuan/berpendidikan, rasional, (2) Berdaya Politik, (3) Berdaya ekonomi (Berdaya saing), (4) Menjunjung tinggi hukum dan (5) Didasari keimanan (ketuhanan yang maha esa) dengan semangat keberagaman agama yang inklusif (Tjokroamidjojo, 2003, 46).

Selain itu civil society diartikan pula organisasi lokal/ kemasyarakatan yang berinteraksi dalam fungsinya yang paling tepat bagi masingmasing (Tjokroamidjojo, 2003, 72). Civil society disini turut berpartisipasi dalam jalannya sistem Governance. Selain itu juga elemen penting lainnya yaitu adanya posisi tawar warga terhadap pemerintah dalam penyelenggaraan urusan publik (Sumarto, 2004, 98). Meskipun Governance mengimplikasikan terjadinya pengurangan peran pemerintah, pemerintah sebagai institusi tidak dapat ditinggalkan begitu saja.

Good Governance penyelenggaraan pemerintahan yang baik dan bertanggung jawab, didasarkan pada dua aspek pokok yang pertama, nilai yang menjunjung tinggi keinginan atau kehendak masyarakat dan nilai yang dapat meningkatkan kemampuan rakyat dalam meraih kemandirian dan terciptanya keadilan sosial (Suparto, 2008, 66). Kedua, pelaksanaan pemerintahan yang efektif dan efisien dalam pelaksanaan tugasnya (Suparto, 2008, 66). 


\section{Penutup}

E-Government untuk mencapai Good Government adalah sebuah keniscayaan walaupun masih banyak kelemahan disana-sininya dalam implementasinya namun dalam keadaan seperti itu $E$ Government harus tetap dilakukan sebagai upaya untuk meningkatkan pelayanan kepada masyarakat khususnya di Kota Malang menuju pelayanan yang prima dan nyaman serta aman bagi masyarakatnya untuk itu melihat pentingnya peran E-Governmet maka dilakukan pengkajian untuk mengetahui Pelaksanaan E-Government di Indonesia khususnya di Kota Malang dan hasil yang telah dicapai hingga saat ini serta kedala-kendala yang menghambat pelaksanaanya sehingga mau tidak mau strategi pelaksanaan dan konsep E-Government memerlukan perbaikan di semua sisi haruslah di jadikan sebagai motivasi membangun yang lebih baik. Keterlambatan E-Government dalam pembangunan hanya akan menjadikan negara ini tetap jauh dari cita cita reformasi, peningkatan kualitas pelayanan publik kepada seluruh masyarakat dan pada akhirnya dapat meningkatkan kesejahteraan mereka melalui peningkatan efisiensi birokrasi dan menyadari pencapaian tata kelola pemerintahan yang baik. Pelaksanaan E-Government harus memperhatikan kesiapan pemerintah dan masyarakat, menurut prinsip dasar dan secara bertahap.

\section{DAFTAR PUSTAKA}

\section{Buku}

Tjokroamidjojo, Bintoro, 2003, Reformasi Nasional Penyelenggaraan Good Governance dan Perwujudan Masyarakat Madani, Lembaga Administrasi Negara, Jakarta.

Birokrasi pada Era Desentralisasi dan Otonomi Daerah, Insan Cendikia, Surabaya.

Budhijanto, Danrivanto, 2010, Hukum Telekomunikasi, Penyiaran dan Teknologi Informasi: Regulasi dan Konvergensi, Refika Aditama, Bandung.

Sumarto, Hatifah SJ., 2004, Inovasi, Partisipasi dan Good Governance 20 Prakarsa Inovatif dan partisipatif di Indonesia, Yayasan Obor Indonesia, Jakarta.

Widodo, Joko, 2001, Good Governance Telaah dari Dimensi Akuntabilitas dan Kontrol

Suparto, Peni, 2008, Paradigma dan Implementasi Pelayanan Publik, Kanisius, Yogyakarta.

Indrajit, Richardus Eko, 2002, Electronic Government Strategi Pembangunan dan Pengembangan Sistem Pelayanan Publik Berbasis Teknologi Digital, ANDI, Yogyakarta.

\section{Artikel dari Jurnal Ilmiah}

Suparto, Peni, 2006, Implementasi E-Government Melalui Pembangunan Jaringan "Malang Online", Disampaikan pada Konferensi Nasional Teknologi Informasi \& Komunikasi untuk Indonesia, Bandung. 